\title{
Development of Safe Two-Store Minimalist Type of Residential House Against COVID-19, Based on Local Wisdom of the Bugis, and Environmental Insight
}

\author{
Muhammad Ardi ${ }^{1}$, Mithen Lullulangi ${ }^{1}$, Hamzah Nur ${ }^{2}$, Faizal Amir ${ }^{3}$, Bakhrani Abdul Rauf ${ }^{1}$, \\ Alimuddin Sa'ban Miru ${ }^{4}$ \\ ${ }^{1}$ Department of Civil Engineering Education and Planning, Universitas Negeri Makassar, Makassar, Indonesia \\ ${ }^{2}$ Department of Mechanical Engineering Education, Universitas Negeri Makassar, Makassar, Indonesia \\ ${ }^{3}$ Department of Automotive Engineering Education Universitas Negeri Makassar, Makassar, Indonesia \\ ${ }^{4}$ Department of Electrical Engineering Education, Universitas Negeri Makassar, Makassar, Indonesia
}

Email address:

m.ardi@um.ac.id (M. Ardi), mithen@unm.ac.id (M. Lullulangi), ayyun_fadel@yahoo.com (H. Nur), Faizalamir64@unm.ac.id (F. Amir), bakhrani@unm.ac.id (B. A. Rauf), alimuddin.smiru@unm.ac.id (A. S. Miru)

\section{To cite this article:}

Muhammad Ardi, Mithen Lullulangi, Hamzah Nur, Faizal Amir, Bakhrani Abdul Rauf, Alimuddin Sa'ban Miru. Development of Safe TwoStore Minimalist Type of Residential House Against COVID-19, Based on Local Wisdom of the Bugis, and Environmental Insight. International Journal of Architecture, Arts and Applications. Vol. 7, No. 3, 2021, pp. 56-61. doi: 10.11648/j.ijaaa.20210703.11

Received: July 21, 2021; Accepted: August 2, 2021; Published: August 18, 2021

\begin{abstract}
This study intends to explore the values of local wisdom of the Bugis tribe, in building houses, which are associated with the current situation of the COVID-19 Pandemic. The purpose of this study was to find: (1) the development of a minimalist, two-story type residential design that is safe against COVID-19, based on local wisdom of the Bugis Tribe, and environmentally friendly, (2) steps for implementing the design, and (3) supporting factors and impediments to design development. Research locations in the Districts: Bone, Soppeng, and Wajo. The research sample was 300 people, selected by purposive sampling. The research variables are: (1) visible design development, (2) design implementation steps, and (3) supporting factors and inhibiting design development implementation. Data analysis technique, is a qualitative descriptive analysis. After concluding the analysis, the next step is to develop the design. The results of the research on the design development of a minimalist, two-story type residential house that are safe against COVID-19, based on local wisdom of the Bugis Tribe, and environmentally friendly, show that: 1) Front view seen from: (a) the position of the sun facing east, (b) contour the ground is facing a higher and flatter direction, (c) the position of the road facing the main highway, (d) the slope of the roof is 25-30 degrees, and (4) the shape of the roof, gable and shield. 2) Steps for implementing the design: (a) conducting socialization, (b) providing explanations about healthy houses and local wisdom of the Bugis Tribe, and (c) collaborating with relevant stakeholders. 3) Factors supporting the implementation of the design are: (a) affordable selling prices for low-income earners, (b) available land for house development and green open land, (c) house designs are classified as healthy, and (d) available roads, water facilities clean, and electric facilities. The inhibiting factors are: (a) the Bugis forget their local wisdom, (b) the planning consultants and developers do not understand the local wisdom of the Bugis.
\end{abstract}

Keywords: Visible Design, COVID-19, Minimalist Type, Local Wisdom, Bugis

\section{Introduction}

Population growth in the era of the COVID-19 Pandemic has an impact on the provision of healthy and safe housing against COVID-19. Law No. 32 of (2009) explains that, in building a house, one should take advantage of the environment as needed to keep it sustainable [1]. Trainer (2011) states that, in building, one should use natural resources as needed [2]. Muhammad Ardi (2017) states that residential houses should have a floor plan design, look, and supporting facilities that are beautiful, efficient, the construction is safe, has social, cultural values, and is a place for families to rest and joke. Culture or local wisdom cannot 
be separated from the design of houses that are safe against COVID-19 [3]. Marfai (2012) states that local wisdom is another form of environmental ethics, namely a set of knowledge obtained through the process and learning of a group of people [4].

The construction of residential houses by developers, as well as those built by the Bugis people themselves, continues. Development does not pay attention to the danger of COVID-19, local wisdom of the Bugis Tribe, and sustainable environmental aspects. The design development of a minimalist, two-story type residential house that is safe against COVID-19, based on local wisdom of the Bugis Tribe, and environmentally friendly is not yet available to consultants, planners, residential developers and other stakeholders, while market demand is quite high.

This study aims to determine: (1) the development of a minimalist, two-story type residential design that is safe against COVID-19, based on local wisdom of the Bugis Tribe and environmentally friendly, (2) steps for implementing the design, and (3) supporting and hindering factors in implementing the design. the development of a design that looks like a minimalist, two-story type residence that is safe against COVID-19 based on the local wisdom of the Bugis Tribe which is environmentally friendly.

\section{Theoritical Review}

In Law No. 4 Year (1992) it is stated that, a house is a building that functions as a residence and a means of fostering a family [5]. Muhammad Ardi (2017) states that, a house is a residence that meets the requirements of a decent life [3]. Muhammad Ardi (2018) states that the house is a place where humans live, carry out the socialization process, interact socially and introduce culture [6].

Muhammad Ardi (2017) states that, to build a residential house that is environmentally friendly, a strategy is needed that can accommodate human aspirations and desires, while still paying attention to a sustainable environment [3]. Nurhasan (2010) states that the house is the main place to increase the potential of human resources for all its residents, which plays a strategic role in improving the morality of the people [6].

Design is something related to human life. Armstrong (2009) states that, design is a personal activity that grows from the creative impulse of an individual [7]. Nurhasan (2010) stated that the development of residential design is largely influenced by social, economic, physical factors [6]. Pambudi and Krisna (2014) stated that, things that need to be considered in designing a house are construction costs and building material prices [8]. Edwin (2016) states that design is the process of organizing everything before acting [9].

Hamzah (2013) states that, local wisdom is a source of knowledge that is dynamically organized, developed and passed on by certain populations that are integrated with their understanding of nature and the surrounding culture [10]. Adyana (2012) states that local wisdom is a local advantage that relies on values, norms, ethics, knowledge, technology, and behavior possessed by a community group and is traditionally institutionalized that is used to overcome life and life problems [11]. Gobyah in Muhammad Ardi (2018) states that local wisdom is a product of past culture that should be continuously used as a guide for life [12].

Ahira (2011) states that, the environment is everything that is around us in the form of living things, be it humans, animals, or plants [13]. Muhammad Ardi (2018) states that, the environment is a living system in which there is human intervention in the order of the ecosystem [12]. Adnani (2011) divides the environment into 3 parts, namely: the biological environment, the physical environment, and the social environment [14]. Muhammad Ardi (2018) stated that the environment consists of three important components, namely abiotic environment, biotic environment, and cultural environment [12]. Yulius Nyerere in Mesaki (2011) states that "In development, mainsthepurpos [15]. Bruntland (1987) states that, sustainable development is development to meet the needs of the present generation without compromising the right of future generations to meet their needs [16].

\section{Research Methods}

The location of this research is in the Districts: Bone, Soppeng, and Wajo. The research population is the Bugis people in the districts of Bone, Soppeng, and Wajo as many as 1,497,661 (Population Census in 2020). The research sample was selected using a purposive sampling method, namely the Bugis people who are well acquainted with local wisdom related to housing. The sample size for each district is 100 people, so the total sample is 300 people. The research variables are as follows: (1) visible design development, (2) design implementation steps, (3) supporting and inhibiting design implementation factors. The data collection instrument consisted of three types, namely: (1) a visible design development questionnaire, (2) a questionnaire on steps for implementing design development and (3) a questionnaire on factors supporting and hindering design development. Data was collected by giving questionnaires to each sample in Bone, Soppeng, and Wajo Regencies. The analysis used is descriptive qualitative analysis.

\section{Research Results and Discussion}

\subsection{Research Results}

\subsubsection{Development of a Front View Design of a Two-Story Minimalist House of Living Bugis Tribe}

\section{(i) Based on the Position of the Sun}

To find out the front view design of a minimalist two-story residential house that is safe against COVID-19, based on local wisdom of the Bugis Tribe, and environmentally friendly based on the position of the sun, the following is the frequency distribution of the development of the front view design of a minimalist two-story house based on the position of the sun in Table 1. 
Table 1. Development of Residential Front View Design Two-story minimalist type based on the position of the sun.

\begin{tabular}{lllll}
\hline No. & Description & Frequency & $\begin{array}{l}\text { Percentage } \\
(\mathbf{\%})\end{array}$ & $\begin{array}{l}\text { \% } \\
\text { Cumulative }\end{array}$ \\
\hline 1 & East direction & 220 & 73,3 & 73,3 \\
2 & West direction & 30 & 10 & 83,3 \\
3 & North direction & 30 & 10 & 93,3 \\
4 & South direction & 20 & 6,7 & 100 \\
& Amount & 300 & 100 & - \\
\hline
\end{tabular}

Based on the frequency distribution in Table 1, it shows that $73.3 \%$ of respondents stated that the front view faces east, $10 \%$ each faces west and north, and $6.7 \%$ faces south. On this basis, it can be concluded that the development of the front-facing design of a minimalist, two-story house that is safe against COVID-19, is based on local wisdom of the Bugis Tribe, and is environmentally friendly, facing east. The east direction is interpreted as: (1) the source of life for all living things, (2) the giver of energy and good health.

\section{(ii) Based on Soil Contour}

To find out the front view design of a minimalist two-story house that is safe against COVID-19, based on local wisdom of the Bugis Tribe, and environmentally friendly based on the contours of the land, the following is a distribution of the frequency distribution of the front view design of a minimalist two-story house based on the contours of the land. in Table 2.

Table 2. Development of Residential Front View Design Two-story minimalist type based on the contour of the land.

\begin{tabular}{lllll}
\hline No & Description & Frequency & $\begin{array}{l}\text { Percentage } \\
(\%)\end{array}$ & $\begin{array}{l}\% \\
\text { Cumulative }\end{array}$ \\
\hline 1 & Towards the high & 190 & 63,3 & 63,3 \\
2 & In the low direction & 0 & 0 & 63.3 \\
3 & In a flat direction & 110 & 36,7 & 100 \\
4 & Towards the sea/river & 0 & 0 & - \\
& Amount & 300 & 100 & - \\
\hline
\end{tabular}

Based on the frequency distribution in Table 2, it shows that $63.3 \%$ of respondents stated that based on the contours of the land, namely facing a higher direction, $36.7 \%$ faced a flat direction. On this basis it can be concluded that the development of the front view design of a minimalist twostory house based on the contours of the land is facing a higher and flat direction. A place or direction that is higher and flat is interpreted as follows: (1) the fortunes of the family who inhabit the house are getting better day by day, (2) the family who inhabit the house has the motivation, creativity to move forward and achieve a better life, (3) All humans in the sight of Allah are equal, and (4) sustenance descends from above, namely from Allah the Almighty.

\section{(iii) Based on Road Condition}

To find out the front view design of a minimalist two-story house that is safe against COVID-19, based on local wisdom of the Bugis Tribe, and environmentally friendly based on road conditions, the following is a distribution of the frequency distribution of the front view design of a minimalist two-story house based on road conditions., in Table 3.

Table 3. Development of Residential Front View Design Two-Story Minimalist Type Based On Road Conditions.

\begin{tabular}{lllll}
\hline No & Description & Frequency & $\begin{array}{l}\text { Percentage } \\
\text { (\%) }\end{array}$ & $\begin{array}{l}\text { \% } \\
\text { Cumulative }\end{array}$ \\
\hline 1 & To the main highway & 270 & 90 & 90 \\
2 & To the second road & 30 & 10 & 100 \\
3 & To the alley way & 0 & 0 & - \\
4 & to any way & 0 & 0 & - \\
& Amount & 300 & 100 & - \\
\hline
\end{tabular}

Based on the frequency distribution in Table 3, it shows that $90 \%$ of respondents stated that the front view of a minimalist, two-story type house that is safe against COVID19 , is based on local wisdom of the Bugis Tribe, and is environmentally friendly, is facing the main highway. On this basis, it can be concluded that the development of the front view of the minimalist type of two-story residential house is facing the main road. A house that faces the main highway is interpreted as a house that has good fortune and lots of it.

\section{(iv) Roof Slope}

To find out the development of the roof slope design of a minimalist two-story house that is safe against COVID-19, based on the local wisdom of the Bugis Tribe, and environmentally friendly, the following is the frequency distribution of the roof slope design of a two-story minimalist type of residence in Table 4.

Table 4. Design of a two-story minimalist type of house roof slope.

\begin{tabular}{lllll}
\hline No & Description & Frequency & $\begin{array}{l}\text { Percentage } \\
(\mathbf{\%})\end{array}$ & $\begin{array}{l}\text { Cumulative } \\
\text { Percentage }\end{array}$ \\
\hline 1 & 30 degrees & 150 & 50 & 50 \\
2 & 25 degrees & 130 & 43,3 & 93,3 \\
3 & 20 degrees & 20 & 6,7 & 100 \\
4 & Less than 20 degrees & 0 & 0 & - \\
& Amount & 300 & 100 & - \\
\hline
\end{tabular}

Based on the frequency distribution of Table 4, it can be seen that $50 \%$ of respondents stated that the slope of the roof of a minimalist two-story house that is safe against COVID19, based on local wisdom of the Bugis Tribe, and environmentally friendly is 30 degrees. A total of $43.3 \%$ stated 25 degrees. On this basis it can be concluded that the development of the design of the roof slope of a two-story minimalist house is 25 to 30 degrees. Such a slope of the roof is interpreted as an authoritative, safe, and strong house.

\section{(v). Roof Shape}

To find out the development of the design of the roof of a minimalist type of two-story residential house that is safe against COVID-19, based on local wisdom of the Bugis Tribe, and environmentally friendly, the following is the frequency distribution of the development of the design of the roof of a minimalist type of two-story residential house in Table 5. 
Table 5. Development of a Two-Story Minimalist Type of Residential Roof Design.

\begin{tabular}{lllll}
\hline No & Description & Frequency & $\begin{array}{l}\text { Percentage } \\
(\%)\end{array}$ & $\begin{array}{l}\text { Cumulative } \\
\text { Percentage }\end{array}$ \\
\hline 1 & Gable & 183 & 61 & 61 \\
2 & Shield & 117 & 39 & 100 \\
3 & Gable and Shield & 0 & 0 & - \\
4 & Any shape & 0 & 0 & - \\
& Amount & 300 & 100 & - \\
\hline
\end{tabular}

Based on the frequency distribution in Table 5, it shows that $61 \%$ of respondents stated that the design development of a gable or triangular roof shape, $39 \%$ was in the form of a shield or a terrapesuim. On this basis it can be concluded that the development of the design of the roof of a two-story minimalist type of house roof is in the form of a gable and a shield. The symbol holds a message or is interpreted as: (a) the prohibition of doing evil to fellow humans and even other creatures, and (b) a safe and peaceful life.

\subsubsection{Steps to Implement the Development of a Two-Story Minimalist Residential Design}

\section{(i) Socializing}

Of the 300 samples analyzed, $94.3 \%$ of respondents stated that the first step to implementing the design was to conduct socialization. On this basis it can be concluded that conducting socialization to all relevant parties is the first step to implementing the development of a two-story minimalist type of residential design.

\section{(ii) Explaining the Local Wisdom of the Bugis}

Of the 300 samples analyzed, $98.3 \%$ of respondents said that the second step to implementing the design was to explain the local wisdom of the Bugis tribe related to housing. On this basis, it can be concluded that explaining the local wisdom of the Bugis Tribe in relation to housing to all relevant parties is the second step to implementing the development of a minimalist two-story type residential design.

\section{(iii) Explaining a Healthy Home}

Of the 300 samples analyzed, $92 \%$ of respondents said that the third step to implementing the design was to describe a healthy home. On this basis, it can be concluded that explaining a healthy home to all relevant parties is the third step to implementing a two-story minimalist type of residential design.

\section{(iv) Cooperate with Relevant Stake Holders}

Of the 300 samples analyzed, $96 \%$ of respondents stated that the fourth step to implementing the design is to work with relevant stakeholders. On this basis, it can be concluded that collaborating with relevant stakeholders is the fourth step to implementing a two-story minimalist type of residential design.

\subsubsection{Supporting and Inhibiting Factors in the Development of Two-Story Minimalist Residential Designs}

\section{(i) Supporting Factors}

1) Selling Price
Of the 300 samples analyzed, it turned out that $92.7 \%$ said that the selling price of a two-story minimalist type of residence was still affordable for the middle and lower economic class. On this basis it can be concluded that the selling price of the house is a supporting factor for the development of a minimalist two-story type residential design.

2) Availability of Rooms and Rooms that Have Ventilation and Lighting

Of the 300 samples analyzed, it turned out that $98.3 \%$ said that the rooms had good air ventilation and lighting, so they were healthy to live in. On this basis it can be concluded that the availability of ventilation and lighting in every room is a supporting factor for the development of a minimalist twostory type residential design.

3) Availability of Land for House Development

Of the 300 samples analyzed, it turned out that $90.7 \%$ said that the availability of land for the development of a twostory minimalist type of residence is very possible. On this basis it can be concluded that the availability of land for the development of a minimalist two-story Bugis house based on local wisdom of the Bugis Tribe, safe against COVID-19, and environmentally friendly is a supporting factor for the development of a two-story minimalist type of residence.

4) Availability of Road, Clean Water and Electricity Facilities

Of the 300 samples analyzed, it turned out that $96 \%$ said that the availability of roads, clean water, and electricity for the development of a two-story minimalist type of residential design was very available. On this basis, it can be concluded that the availability of roads, clean water, and electricity for the development of a minimalist two-story Bugis house design based on local wisdom of the Bugis Tribe, safe against COVID-19, and environmentally friendly are factors supporting the development of residential design. two-story minimalist type.

\section{(ii) Obstacle Factor}

1) The Bugis Have Forgotten Their Local Wisdom

Of the 300 samples analyzed, it turned out that $85.3 \%$ stated that the Bugis had forgotten the local wisdom of their ancestors related to their homes. On this basis it can be concluded that the Bugis do not recognize their local wisdom anymore, so that building houses tends to be dominated by modern thinking and is an inhibiting factor in the development of minimalist two-story type residential designs.

2) Residential Planning Consultant

Of the 300 samples analyzed, it turned out that $88 \%$ said that the housing planning consultant did not understand and consider the local wisdom of the Bugis. Planning consultants design residential houses based on profit thinking, and land efficiency so that aspects of local wisdom, home health, and a sustainable environment are forgotten. On this basis, it can be concluded that the planning consultant who does not understand the local wisdom of the Bugis is an inhibiting factor in the development of a minimalist two-story type of Bugis residence design. 


\section{3) Housing Developer}

Of the 300 samples analyzed, it turned out that $90.3 \%$ stated that housing developers did not understand and consider the local wisdom of the Bugis Tribe in designing and building residential houses. Developers only think about the benefits and efficiency of land and buildings. Therefore, it can be concluded that the developer is an inhibiting factor in the development of a minimalist two-story Bugis residential design.

\subsection{Discussion}

The results showed that the development of the front view design of a minimalist, two-story residential house that was safe against COVID-19, was based on the local wisdom of the Bugis Tribe, and was environmentally friendly from the aspect of the sun's position facing east. The east is interpreted as: (a) is the place where the sun rises which means the beginning of life, (b) the sunlight appears from the east and gives light to the universe which means a good source of life, and (c) is a source of fortune for all humans. Thus the east direction is the best front of the house based on the philosophy of the Bugis Tribe.

The front of the house from the side of the land contour is facing a higher and flatter place. The Bugis will choose to face a higher and flat direction. A higher and flatter direction is interpreted as a house that has good fortune. In other words, the occupants of the house will have good fortune, the day is getting better. In addition, the Bugis also understand that all humans before God are equal. The difference is perseverance, motivation, creativity, discipline, sincerity, and the power of imagination possessed by humans.

The front of the house seen from the road position is facing the main highway. The Bugis chose the front of the house to face the main road. This means that a house facing the main highway has a lot of and continuous fortune.

The slope of the roof for a two-story minimalist type of residence is 25 to 30 degrees. The Bugis interpret that the slope of the roof is so authoritative, strong and safe to live in. The shape of the roof of a minimalist two-story house is in the form of a gable and a shield. Based on the local wisdom of the Bugis tribe, the shape of the gable and shield is all tapered up, down, left, and right. The gable and shield symbolize safety, love and peace. The Bugis interpret it as a house full of safety and peace. A house with such a roof shape, the occupants are safe, full of peace, love, and full of safety.

The supporting factors for implementing the development of a minimalist, two-story type residential design that are safe against COVID-19, based on local wisdom of the Bugis Tribe, and environmentally friendly are: (a) the selling price of the house is affordable by the low-income community, (b) the development of house designs classified as houses healthy, (c) the availability of land for the development of houses and green open land, (d) the availability of roads, clean water, and electricity. These factors need to be maintained so that the application of a minimalist type of residential design will give birth to a healthy settlement. The inhibiting factors are: (a) many Bugis have abandoned their local wisdom, (b) planning consultants and developers do not understand the local wisdom of the Bugis. Planning consultants and developers are profit oriented. These factors need to be controlled.

\section{Conclusion}

The conclusions of this study are as follows: 1) Development of a front view design of a minimalist, twostory Bugis house that is safe against COVID-19, based on local wisdom of the Bugis tribe, and environmentally friendly: (a) viewed from the position of the sun facing east, (b) viewed from the contour of the land facing to a higher and flatter direction, (c) viewed from the position of the road facing the main highway, (d) the roof slope is 25 - 30 degrees, and (e) the shape of the roof is gable and shield, 2) The steps for implementing the design development are: (a) conducting socialization, (b) explaining the local wisdom of the Bugis tribe related to housing, (c) explaining healthy housing, and (d) collaborating with relevant stakeholders, and 3) Supporting factors for implementing the design development of a minimalist, two-story Bugis type house that is safe against COVID-19, based on local wisdom of the Bugis, and environmentally friendly: (a) affordable selling price for lowincome people, (b) design the house is classified as healthy, (c) land is available for house development and green open land, (d) available roads, clean water, and electricity. The inhibiting factors are as follows: (a) the Bugis people abandon their local wisdom, (b) the planning consultants and developers do not understand the local wisdom of the Bugis.

\section{Acknowledgements}

Acknowledgments are conveyed to: 1) Ministry of Research and Technology/National Research and Innovation Agency and Higher Education who have funded this research as a form of guidance for lecturers in Higher Education; 2) Rector of Universitas Negeri Makassar for his permission, guidance, and motivation; 3) Chairman of the Institute for Research and Community Service (LP2M) Universitas Negeri Makassar, for his support and direction; 4) The District Governments of Bone, Soppeng, and Wajo for granting permission to conduct research; 5) All members of the research team for their good cooperation, and 6) All parties who have participated in this research. Hopefully what has been done will provide the greatest benefit to Universitas Negeri Makassar, the Society, the Nation and the State.

\section{References}

[1] Undang-Undang R. I. Nomor 32 Tahun 2009 Tentang Perlindungan dan Pengelolaan Lingkungan Hidup.

[2] Trainer, Ted. 2011. The Radical Implication of a Zero Growth Economy 1 (http://rwer.wordpress.com/2011/09/06/rwerissue-57-Trainer/, diakses 15 September 2018). 
[3] Muhammad Ardi, Bakhrani A. Rauf, dan Mithen. 2017. Desain Rumah Tinggal Berbasis Kearifan lokal Suku Bugis Yang Berwawasan Lingkungan. Makassar: Badan Penerbit UNM.

[4] Marfai. 2012. Pengantar Etika Lingkungan dan Kearifan Lokal. Yogyakarta: UGM Press.

[5] Undang-Undang R. I. No. 4 Tahun 1992 Tentang Perumahan dan Permukiman.

[6] Nurhasan, Indrawati dan Riza Zahrul Islam. 2010. "Pendekatan DesainRumah Sederhana Sehat (rs sehat) dan LingkungannyaBerdasarkan Arsitektur Islam." Laporan Penelitian. Solo: Universitas Muhamadiyah Solo.

[7] Armstrong, Helen. (2009) Graphic Design Theory Reading From The Field. (Terjemahan: Indrajaya, Erastus Hans). Yogyakarta: Penerbit Andi.

[8] Pambudi, Gandi Bagus dan Krisna Dwi Handayani. 2014. Analisis Kesuaian Desain Rumah Terhadap Konsep Greenship Home pada Perumahan Menengah ke Atas di Kota Gresik. https://drive.google.com/file/d/0B3veF_xJ1onYMWFBY29T N29hd1E/view. Diakses 13 Mei 2019.

[9] Edwin, dkk. 2016. "Perancangan Rumah Tinggal." https://www.academia.edu/28635798/perancangan_rumah_tin ggal). Diakses 13 Mei 2019.
[10] Hamzah, M. 2013. Pendidikan Lingkungan, Sekelumit Wawasan Pengantar. Bandung: Refika Aditama.

[11] Adyana, P. 2012. Wacana Tembang Macapat sebagai Pengungkap Sistem Kognisi dan Kearifan Lokal Etnik Jawa. Publikasiilmiah.ums.ac.id. Volume 2. No. 22. Desember 2012.

[12] Muhammad Ardi, Mithen, Bakhrani A. Rauf, dan Faizal Amir. 2018. Desain Tampak Rumah Tinggal Berbasis Kearifan Lokal Suku Bugis Yang Berwawasan Lingkungan. Makassar: Badan Penerbit UNM.

[13] Ahira, Anne. 2011. Kesehatan Lingkungan Perumahan. (ww.anneahira.com/kesehatan-lingkungan-permukiman.htm, diakses 22 April 2019).

[14] Adnani. 2011. Ilmu Kesehatan Masyarakat. Cetakan 1. Yogyakarta: Nuha Medika.

[15] Mesaki, Simeon; and Malipula, Mrisho. 2011. "Julius Nyerere's influence and legacy: From a Proponent of familyhood to a candidate for sainthood". International journal of Sociology and Antropology. Vol. 3 (3) pp. 093-100, March 2011. Available online https://academicjournals.org/journal/IJSA/article-abstract/7 DBC2502079, diakses 22 April 2019.

[16] Bruntland, G. H. (1987), "World Commission on Environment and Development", in "Our Common Future", Oxford: Oxford University Press. 